\title{
Editorial
}

\section{Giving the devil his due: General Franco and Spanish brand 'miracle'}

Place Branding and Public Diplomacy (2015) 11, 245-248. doi:10.1057/pb.2015.15

All fields of research or practice have their clichés: their well-worn examples that when repeated or even alluded to set the initiated nodding sagely. In our realm of place and nation brand studies, a favourite claim holds that the astute application of re-branding and mega-event hosting changed the international image of Spain from one of a crumbling Fascist pariah ruled by General Franco to fashionable European powerhouse in the space of just a few short years. The claim sprang into the nation brand discourse in its formative phase. It was part of brand guru Wally Olins' standard shtick surfacing in his influential pamphlet for the Foreign Policy Centre from 1999: Trading identities: Why countries and companies are becoming more alike. It was also the headline claim a widely cited piece by Gilmore (2002) for a special issue of Brand Management: 'A Country: Can it be repositioned? Spain - the success story of country branding'. The basic story is this, as recounted by Olins in November 2001:

$[O]$ nly a generation ago Spain was in a similar situation to Poland today. For the first half of the 20th century (and for a century before that) Spain did not count in Europe; it was isolated, backward, poor and undemocratic. Today it has transformed itself into a well-off, respected European democracy. The reality has changed and so has the image. Spain has successfully orchestrated and promoted its re-entry into the European family. The Joan Miro sun symbol was an identifier for a massive promotional programme closely linked to national change and modernisation.
Institutional and tourist advertising on a national and regional level, the creation of successful international business schools, the growth, privatisation and globalisation of Spanish multinationals like Repsol, Telefonica and Union Fenosa, the rebuilding and beautifying of major cities like Valencia, Barcelona and Bilbao, the self-mocking, sexually explicit tragicomic films of Almodovar and his contemporaries, political devolution, the Barcelona Olympics and the Seville International Exhibition of 1992, the prestige and influence of European statesmen like Javier Solana, all underline and exemplify the change. (Olins, 2001)

Both Olins and Gilmore were careful to emphasize that the Spanish transition was based on planned realities. Olins noted: '.. Spain is among the best examples of modern, successful national branding because it keeps on building on what truly exists; it incorporates, absorbs, and embraces a wide variety of activities to form and project a loose and multifaceted yet coherent, interlocking, mutually supportive whole'. However in subsequent citation their arguments have become less nuanced. The marketing element has been allowed to trump the wider context. Miro's sun symbol has shifted into not merely a symbol of the transformation but its driver in a variation on the age-old 'post hoc ergo propter hoc' fallacy. The Spanish case often functions as the 'before/after' icon: the place brand consultant's equivalent of Jeffrey Life, MD, the absurdly buff septuagenarian surgeon 
whose image is used to promote the Cenegenics anti-aging programme in innumerable in-flight magazines and Web-pop-ups, or Jared Fogel, the formerly obese American who lost weight after switching to Subway sandwiches and became a feature of the chain's TV ads for a decade and a half. ${ }^{1}$ Identifying a brand with a single case is always a risky strategy. Subway realized this when Fogel was charged with child-sex offences earlier this year. The centrality of the Spanish case is hardly less of a liability for the field of place branding, not merely because Spain itself has lost some of its shine since the economic downturn but also because the transition seems not to have been quite as sudden or dramatic as Olins or Gilmore would have it. What if the Jared of nation branding was already 'losing weight' before going to the place branding 'Subway'? Both the argument for a nuanced account of the Spanish transformation and an alarm bell over the uncritical citation of Olins and Gilmore are important elements in a new book by media historian Neal Rosendorf: Franco Sells Spain to America: Hollywood, tourism and public relations as Postwar Spanish Soft Power. Our field would do well to pay attention.

Rosendorf is an unusual scholar. Trained at Harvard in the 1990s by Joseph Nye, Akira Iriye and Ernest May he was a late entrant to academia owing to a career as a musician. His first singleauthored book - published in Palgrave's distinguished 'Studies in the History of the Media' series - is a tour de force, bringing together archival work in the United States and Spain, adding material from personal interviews with significant participants and deftly blending insights from relevant fields including history, international relations, communication studies, public relations and place branding. Rosendorf is a skilled storyteller and puts together an impressive account of exactly how the repositioning of Spain was begun and greatly advanced by the very man who is used to symbolize intransigence and the absence of transformation in the standard account: General Francisco Franco. In writing about Franco in this way Rosendorf shows a degree of intellectual courage. The world loves its villains and doesn't always welcome nuance or a complex treatment of a formerly black and white case. Rosendorf is explicit in his personal revulsion at Franco's values but writes on in the principle of 'giving the devil his due'.

Rosendorf opens as one might expect with an exploration of the depth of Spain's image problem at the end of World War Two following the fall of Franco's allies Adolf Hitler and Benito Mussolini, and the challenges associated with the aftermath of the Spanish Civil War a decade earlier, which had given Spain the kind of bleak image we saw in turn of the millennium Lebanon or contemporary Iraq. Prudence required accommodation with Spain's European neighbours and a major effort to cultivate the American public and politicians. Franco duly began his country's long road back from pariah status by cultivating links with USbased journalists, businesses and travel writers. Rosendorf pays especial attention to the work of the international public relations consultants retained by the regime. Key moments include the creation of the slogan that relaunched Spain's 1950s tourist advertising: 'Spain is different', and the government's deals with the airline TWA and Hilton hotels to promote Spain as a high-end travel destination for the US market (in contrast to its mass-tourist positioning in Western Europe). The analysis of the manipulation of American travel writing is especially interesting. Franco ended up giving medals to the writers who gave Spain a good press.

The second wave of activity was a campaign of cooperation between the Franco regime and Hollywood in the later 1950s and early 1960s. As one would expect the San Sebastian film festival has an important role to play. More than this Rosendorf works to resurrect the memory of Samuel Bronston, an entrepreneur who tried to launch a Hollywood studio in Madrid in the 1960s, best remembered for epics like The Fall of the Roman Empire (1964) and 55 Days in Peking (1963). While only a few of the films produced actually tackled Spanish themes - El Cid (1961) being the best known - Bronston also created a number of propaganda films for the Spanish government, and did much to normalize a Spanish connection in US popular culture, before overreaching and going bust. Perhaps more cost 
effective in capturing the American imagination was an innovative approach that Rosendorf dubs 'history and place diplomacy'. By the early 1960s the Spanish regime was actively seeking opportunities to develop an awareness of the shared heritage of the United States and Spain. Spain invested in projects like the celebration of the 400th anniversary of the foundation of Saint Augustine, Florida or 250th anniversary of the birth of the Franciscan missionary Father Junipero Serra who moved from his origins on Majorca to colonial Mexico and founded the iconic chain of Catholic missions in colonial California from which most of the state's major cities get their names. Rosendorf shows how modern Spain retroactively wrote itself into American regional and national history with contemporary gain in mind.

Rosendorf's story is not merely about image management. He makes it clear that Franco had to change realities too. One of the ugliest realities of post-war Spain was its intolerance towards all religions except Catholicism. Both Jews and Protestants endured blatant legal and social discrimination. Rosendorf relates how early attempts to justify the inequality or distract attention in the American market gave way to compromise and Franco instituted enough reform to remove the issue from the American public's radar.

The story has its watershed moments. The big breakthrough in Spain's charm offensive in the United States at least was a massive Spanish investment in the New York World's Fair of 1964 and '65. Spain's US\$7000 000 pavilion was considered the jewel of fair: introducing the United States to Spanish fashion, cuisine, design and flair, and - Rosendorf notes - launching sangria in the United States too. Moreover the story is not short on personalities - the most beguiling of which is the irrepressible Minister of Information and Tourism Manuel Fraga Iribarne (1922-2012), interviewed in the writing of the book. Fraga's background included formal academic training in international relations. As well as his direction of the 'Spain is different!' campaign he also relaxed cinema censorship in Spain and was contrasted with his predecessor in the saying $;$ Con Salgado, toto tapado; Con Fraga, hasta la braga! ['With
Salgado all covered; with Fraga you get underwear']. He also memorably joined the US ambassador for a swim in the sea to 'prove' there was no danger after an American B-52 carrying H-bombs crashed off the Spanish coast in $1966 .{ }^{2}$ $\mathrm{He}$ deserves to be remembered beyond his own country's borders as one of the twentieth century's great exponents of propaganda.

Rosendorf's account ends on a down-beat note. The interplay of reforms and outreach largely end in 1969 when Franco fired Fraga and a number of other drivers of change. Spain took a take a turn towards conservatism and political ossification, which helps explain why its image in the days before the 1980s campaign could be characterized so bleakly. However, the second down-beat note is Rosendorf's own exploration of the conventional wisdom within our place and nation branding community that uncritically claims the positive image of Spain was the product of the rebranding campaign after the formal transition to Democracy. Rosendorf is very tough on Olins, Gilmore and those who have cited them without question. In retrospect it is surprising that in Gilmore's 'case study' of Spain only one of a dozen pages deals with the country and the only footnote within that material is a quote from a Guardian column paraphrasing Olin's views (Preston, 1999). ${ }^{3}$ He notes that they speak as practitioners rather than scholars and suggests that their eagerness to identify and celebrate a fast shift in Spain's reputation is probably tied to Olins and Gilmore's work as consultants, and their implicit claim to be able to generate similar reputational shifts if sufficiently remunerated. More seriously, he questions the rigour of a field that can be so unscholarly in its acceptance of one of its key examples, writing in his conclusion: 'It is a disquieting commentary on the state of the field of nation/place branding that one article by a nonacademic researcher whose central argument is predicated on a total fallacy to become so embedded in subsequent scholarship and practitioner analysis ${ }^{4}$.

This is a book that needs to be read and digested by our field. We do not have to forget about Spain and the examples of Miro's sun or the Barcelona Olympics. Rosendorf's refinement of the story 
does not negate the Spanish re-branding achievement, but rather it adds necessary depth and nuance. A long reading of the Spanish case brings it into line with what we know of Germany's journey from being a by-word word for mass-produced tat in the late 1800s to its enviable pre-eminence today. It also bears out the position of Simon Anholt with his emphasis on the need to shift underlying realities over a long term rather than merely manipulating symbols in the short term. We can look forward to further explorations of this story: historians are already at work on the Spanish approach to Western Europe. Rosendorf has no plans himself to write a sequel on Spanish nation branding in the post-Franco period; however, his planned treatment of the early decades of Israeli public diplomacy promises to be hardly less illuminating.

\section{NOTES}

1 In full disclosure, having been much impressed by a live presentation of the Spanish case given by Gilmore at a UNESCO conference in Jordan in December 2005, I have assigned her piece to students and I have certainly used the Spanish case in this way in my standard lectures on both public diplomacy and nation branding. I have always contested the view that the Miro sun was somehow all that was necessary to achieve the 'miracle'.

2 For basic details, see Eaude (2012). Fraga's tourism work is the focus of Crumbaugh (2009).
3 Most of the piece is used to present the holistic models for national 'repositioning' and citizen engagement initially developed for her Springpoint consultancy, and subsequently carried forward by her new consultancy Achanchi for clients including Hong Kong, Dubai and Bahrain as well as England, Northern Ireland and Wales. Details from www.acanchi. com/, accessed 3 September 2015.

4 Rosendorf (2014) cites Keith Dinnie, John Quelch and Katherine Jocz, Melissa Aroncyzk and Ying Fan as uncritical users of the Olins/ Gilmore legend.

\section{REFERENCES}

Crumbaugh, J. (2009) Destination Dictatorship: The Spectacle of Spain's Tourist Boom and the Rejuvenation of Difference. Albany, NY: State University of New York Press.

Eaude, M. (2012) Manuel Fraga obituary, The Guardian, 17 January, http://www.theguardian.com/world/2012/jan/17/ manuel-fraga, accessed 3 September 2015.

Gilmore, F. (2002) A country: Can it be repositioned? Spain The success story of country branding. Brand Management 9(4-5): 281-293.

Olins, W. (2001) Viewpoints: The Image of Spain, Saffron Consultants, November, http://ftp.saffron-consultants.com/ includes/spain.pdf, accessed 3 September 2015.

Preston, P. (1999) Branding is cool - It's Tony Blair's favourite pastime, The Guardian, 14 November, http://www.theguardian.com/politics/1999/nov/15/labour. labour1997to99, accessed 3 September 2015.

Rosendorf, N.M. (2014) Franco Sells Spain to America: Hollywood, Tourism and Public Relations as Postwar Spanish Soft Power. London: Palgrave Macmillan, pp. 198-199.

Nicholas J. Cull University of Southern California 